\title{
O desejo, o direito e o dever - A trama que trouxe a Copa ao Brasil
}

Arlei Sander Damo*

\begin{abstract}
Resumo: Este texto se propõe a discutir os principais eventos, bem como o papel dos agentes e das instituições, que tornaram o Brasil sede da Copa de 2014. O objetivo é desnaturalizar esta escolha mostrando que o país não é sede apenas porque a Federação Internacional de Futebol Associado (FIFA) tem um sistema de rodízio, nem porque existiu um conchavo entre Blatter e Lula. Destaco o protagonismo da FIFA nesse processo, tratando-a como uma agência privada, o que implica em considerar legítimas as suas pretensões de lucrar com a Copa. Procuro mostrar como o governo brasileiro foi sendo seduzido, pelos dirigentes esportivos e pela opinião pública a avalizar a candidatura, pagando por ela um valor econômico altíssimo e contestado, além de correr riscos de sair com seu status arranhado a Copa não seja um sucesso.
\end{abstract}

Palavras-chave: Copa do mundo. Eventos. Futebol. Brasil. Antropologia.

\section{INTRODUÇÃo}

O banheiro do Papa, um filme baseado em fatos históricos, está entre os melhores textos que já se produziu sobre megaeventos ${ }^{1}$. Ele narra o cotidiano de Beto, um morador da cidade uruguaia de Melo, próxima à fronteira sudoeste do Rio Grande do Sul. Beto vive precariamente, com a mulher e uma filha, graças ao contrabando de mercadorias destinadas ao pequeno mercado do bairro onde mora, um trabalho insalubre, arriscado e penoso, pois realizado de bicicleta. O projeto da família é trocar a bicicleta por uma moto e eles já dispõem de uma parte dos recursos. A proximidade da visita de João Paulo II à cidade - que efetivamente ocorreu em 1988 - desperta a imaginação nos habitantes de Melo. Crentes no noticiário local, que

\footnotetext{
'Programa de Pós-graduação em Antropologia Social. Universidade Federal do Rio Grande do Sul. Porto Alegre, RS, Brasil. E-mail: arleidamo@uol.com.br

${ }^{1} \mathrm{O}$ filme foi premiado em diversos festivais: Gramado (Melhor Roteiro, Melhor Filme (Júri Popular e Crítica), São Paulo (Melhor Filme - Júri Internacional) e Huelga (Melhor Roteiro).
} 
estima em 20 mil, 40 mil e até 60 mil o número de visitantes brasileiros, eles esperam faturar muito dinheiro com a passagem do pontífice. Quase todos investem na preparação de quiosques de panchos, a especialidade local. Beto imagina que a visita do pontífice possa render-lhe o tanto que falta para a compra da moto, e por conta disso investe as economias numa ideia original: a construção de um banheiro no quintal de casa - um "banheiro de verdade", diferente daquele que a família dispõe -, afinal com tanta gente comendo tanto pancho, um banheiro haverá de ser indispensável. O vaso será contrabandeado de bicicleta, à última hora. $\mathrm{O}$ banheiro fica pronto, mas o afluxo de fiéis à cidade é frustrante. $\mathrm{O}$ filme é maravilhoso em muitos aspectos, mas corrosivo na sua mensagem.

É difícil saber quantos projetos parecidos com "o banheiro do papa" teremos no Brasil. Os brasileiros crêem na propaganda dos megaeventos, mas também desconfiam. Há muitas críticas, veiculadas até mesmo em grandes redes midiáticas, e talvez isso servirá como antídoto. Todavia, a crítica não tem impedido que certos projetos, questionados desde a origem, marchem a passos largos. É o caso da construção e/ou reforma de alguns estádios ${ }^{2}$, o exemplo mais eloqüente até o presente. Não se poderá alegar, no futuro, que tais gastos foram mal projetados porque não se sabia do risco. A questão é saber como eles foram realizados apesar disso. Dizer que foram obra de governantes inconsequientes é óbvio demais, pois isso seria desconsiderar um cenário muito mais complexo, que não se restringe ao mero cálculo de custos e benefícios.

Quando o Brasil foi dado como o país sede da Copa do Mundo de $2014^{3}$ tinha-se uma ideia ambivalente do que isto significava. $\mathrm{O}$ anúncio foi comemorado pelos brasileiros, mas sem estardalhaço,

\footnotetext{
${ }^{2}$ Apenas como ilustração, cito as críticas, amplamente veiculadas, em diferentes mídias, à construção e/ou reforma dos estádios: Estádio Nacional (Brasília), Arena Corínthias (São Paulo), Estádio das Dunas (Natal), Arena Pantanal (Cuiabá), Arena Amazônia (Manaus) e mesmo o Maracanã (Rio de Janeiro). As críticas variam de um caso a outro, embora algumas sejam partilhadas. As mais graves incluem: utilização de recursos públicos, indícios de superfaturamento ou direcionamento das licitações e inadequação às demandas do futebol local.

${ }^{3}$ Por economia lingüística, sempre que me referir apenas a Copa, fica desde logo estabelecido que é à Copa do Mundo de Futebol Masculino que estou me referindo.
} 
muito diferente do que ocorreria dois anos depois, ocasião em que a cidade do Rio de Janeiro foi definida como a sede dos Jogos Olímpicos de 2016. Será a segunda ocasião em que o Brasil sediará uma copa e a primeira vez que uma de suas cidades organizará os jogos olímpicos, mas não creio que o ineditismo das Olimpíadas seja motivo para explicar a diferença em relação ao primeiro anúncio. A empolgação com a decisão do Comitê Olímpico Internacional (COI), beneficiando o Rio de Janeiro, e certa indiferença em relação à decisão da Federação Internacional de Futebol Associado (FIFA), tem muito a ver com a forma com que as respectivas decisões foram encaminhadas. O COI, como recomenda sua própria tradição, promoveu um concurso que se arrastou por mais de um ano, com duas etapas bem definidas, tendo a última culminado com uma disputa espetacular entre cinco cidades e suas respectivas delegações presentes em Copenhague. A FIFA, como de praxe, faz suas escolhas de forma reservada e no caso daquela envolvendo a Copa de 2014 não havia disputa quando a decisão chegou à etapa de Zurique, onde foi oficializada.

O concurso ou a sua ausência pode ser parte da explicação da diferença em relação à recepção dos respectivos anúncios, mas não é a resposta definitiva para a hesitação em relação à Copa. Em que pese já tenhamos tido uma experiência do gênero, a impressão é de que ela foi apagada da memória - ou quase. De fato, a Copa de 1950 é lembrada menos pelo fato de ter sido realizada no Brasil e mais pelo trauma da derrota da nossa seleção para o Uruguai na final. É sintomático, por exemplo, que tenhamos uma série de produções acerca dessa derrota - que recebeu, inclusive, a designação de "tragédia" - e escassas referências sobre a escolha do Brasil como sede, a preparação dos estádios, a recepção das delegações estrangeiras e outros temas afins ${ }^{4}$. Será isso um indicativo

\footnotetext{
${ }^{4}$ Não temos, de fato, muitos trabalhos sobre aos preparativos para a Copa de 1950. A dissertação transformada em livro, de Gisella de Moura (1998), é uma exceção, ainda que ela trate quase que exclusivamente sobre a construção do Maracanã. Já sobre a derrota para os uruguaios a bibliografia é extensa, mesmo no âmbito acadêmico, o que inclui as teses de Fraga (2009) e Freitas Jr (2009). Para uma apreciação da bibliografia a respeito do significado da derrota para - Uruguai, significado que é, em boa medida, atualizado pela própria bibliografia que recupera e reelabora aquele acontecimento, sugiro uma consulta às respectivas teses, incluindo-se as referências bibliográficas.
} 
de que, em se tratando de copa do mundo, os brasileiros gostam mesmo é de jogá-la, pouco se importando com o local onde a mesma é realizada? Uma resposta definitiva poderá ser dada ao final do evento, quando será possível avaliar com mais acuidade o seu impacto e a opinião pública. O que se pode dizer, no presente, é que ela tem suscitado controvérsias, afinal trocamos a preocupação com a disputa das eliminatórias - a bem da verdade isso nunca foi um problema, pois estivemos em todas as copas - pela expectativa em relação à conclusão das obras, o modo como elas estão sendo financiadas, a corrupção e outras questões do gênero.

Em certo sentido, a copa continua sendo o que sempre foi desde 1930, quando foi disputada pela primeira vez no Uruguai: uma competição entre equipes de futebol que representam Estadosnações. Justamente por envolver representações nacionalistas, a copa possui um forte componente político, mas este é mais relacionado aos afetos do que à diplomacia convencional. Uma copa não inicia nem interrompe animosidades nacionais, quanto menos guerras, embora ela possa suscitar a memória a respeito de velhas ou novas querelas. Sempre que Argentina e Inglaterra se enfrentam a imprensa não deixa de lembrar que os dois países têm um contencioso de longa data. Mais para os argentinos do que para os ingleses, o enfrentamento propicia uma oportunidade de reviver as desavenças. Os argentinos já experimentaram a desforra, pelo menos no plano mimético, em diversas oportunidades, a mais célebre na Copa de 1986, quando Maradona fez um gol com a mão e outro driblando a metade do time inglês. Todavia, as Falklands - que os argentinos continuam chamando de Malvinas - seguem sob o domínio imperturbável da Rainha. Em suma, a copa mobiliza sentimentos nacionais, mas o faz com o único propósito de agregar sentido à disputa futebolística, imiscuindo-se de qualquer tomada de posição política conseqüente.

De outra parte, a Copa é muito mais do que uma competição futebolística, com 66 jogos e duração aproximada de 40 dias. Para a FIFA e suas parcerias comerciais, a Copa é projetada para render dividendos, e nisso consiste um dos aspectos mais polêmicos. 
Diferentemente do que se dizia no momento em que o Brasil de tornou sede, vê-se agora que o poder público terá que bancar a maior parte dos custos da competição. E não se trata de gastos apenas para melhorar a mobilidade urbana, uma das rubricas do caderno de encargos da FIFA que pode resultar em benefícios para além do evento 5 .

Pretendo aqui suscitar algumas questões que dizem respeito ao processo em curso, de preparação do Brasil - de parte dele, ao menos - para a Copa de 2014. Tentarei evitar as posições extremas, tanto dos promotores quanto dos contestadores. Entre os promotores incluo todos aqueles que, por razões diversas, militam favoravelmente à realização do evento e não hesitam em apresentar argumentos visando justificar suas posições e até realizar uma espécie de proselitismo. Não é difícil identificá-los entre os cronistas esportivos profissionais, empresários ligados ao setor imobiliário, de eventos e de transportes, políticos de todas as matizes partidárias, entre outros. Os contestadores constituem um grupo menos visível e mais fluído, pelo menos até o presente, e se concentra na voz de alguns intelectuais, com espaço na mídia, e de movimentos sociais que tentam, às duras penas, articular grupos vulneráveis, que estão sofrendo com diferentes modalidades de inconvenientes gerados pelos preparativos em curso. Ambos têm argumentos consistentes e frágeis.

Os promotores tendem a colocar no rótulo denominado de "legado" um conjunto tão heteróclito e disparatado de elementos que o termo tornou-se arbitrário. Do ponto de vista do significado, legado a muito deixou de ser aquilo que de bom vai restar depois do término do evento para ser uma modalidade de significante flutuante, um termo que comporta tal quantidade de significações que já não

\footnotetext{
${ }^{5}$ Diversos estudos, realizados por urbanistas, têm mostrado que o impacto das obras de mobilidade urbana acarreta em dificuldades para muitas pessoas. Além das desapropriações, que são freqüentes, os preços dos imóveis e dos aluguéis tendem a ser majorados nas áreas próximas a estas obras. Bom para a especulação imobiliária; péssimo para quem depende de aluguel ou está no traçado das vias. Ainda que as obras possam trazer benefícios para a maioria, eles trazem problemas a grupos específicos, em particular aqueles mais vulneráveis, que não tem condições de reivindicar legalmente seus direitos. Sobre o tema vale uma consulta aos trabalhos de Gaffney (2010) e Rolnik (2012).
} 
consegue especificar o que quer que seja. Se isso não bastasse, ainda desdobraram o conceito, o tal de "legado intangível", em torno do qual gravitam o aumento da auto-estima nacional, a exposição do país em escala planetária, a possibilidade de intercâmbio com estrangeiros, a coesão interna e assim por diante. $\mathrm{O}$ que não questionam, jamais, é quem deseja e a quem interessa tudo isso, afora o fato de que é difícil, senão impossível, mensurar a relação custo/benefício dessa parafernália de coisas. Mas o mesmo não se pode dizer dos gastos do poder público, estimado em aproximadamente 30 bilhões de reais até o presente. É claro que não faltam agências informando números a este respeito e outras tantas dando publicidade a eles. Mas poucos questionam a credibilidade de quem faz as projeções, sem falar na metodologia usada. Sobre isso prefiro a opinião respeitada de um dos maiores especialistas em economia do esporte, Wladimir Andreff (2010, p. 16), para quem esses dados difundidos pelas mídias, "[...] se sont au mieux des estimations grossières, au pire des données "pifométriques"6. Victor Matheson (2012, p. 53), outro especialista, vai mais longe, afirmando que "[...] las ligas, los proprietários de los clubes y los próprios promotores de los megaeventos deportivos tienen um interes lógico por maximizar su impacto econômico, com tal de justificar fuertes subvenciones públicas".

Também não compartilho de algumas posições dos contestadores, para quem a copa não seria "nada além do que" uma oportunidade para empresários e políticos amealharem recursos públicos - através da realização de obras supérfluas, do superfaturamento ou do desvio puro e simples de dinheiro para as contas privadas ou dos partidos ${ }^{7}$. Não é que isso não exista, o problema é com relação ao "nada além de", pois fica implícita a ideia

\footnotetext{
6"São na melhor das hipóteses grosseiras, na pior são estimativas pessoais" (tradução do autor).

${ }^{7} \mathrm{~A}$ ideia de sintetizar a posição dos contestadores na fórmula "nada além de..." é inspirada na crítica de Viviana Zelizer (2010) ao reducionismo - econômico, político ou cultural - de algumas vertentes acadêmicas que tratam os mercados de um ponto de vista unilateral. Em contrapartida, Zelizer propõe múltiplas possibilidades de análise e, numa recente publicação no Brasil, que trata da relação entre economia e intimidade, sintetiza tal posição no conceito de "vidas conexas" (p. 17-47).
} 
de que a copa é produto de um complô. $\mathrm{Na}$ melhor das hipóteses formulações desse gênero desdenham o espaço social como um espaço de disputas - políticas, econômicas, ideológicas, etc - e isso vale também para o orçamento do Estado. Nada garante que os 6 bilhões de reais destinados à construção e/ou reforma dos estádios iriam para a saúde, a educação e a assistência social caso a copa não fosse realizada no Brasil. Na pior das hipóteses, a perspectiva do "nada além do que" supõe que os brasileiros sejam alienados.

A copa é um evento planetário de grande impacto local, sendo este concreto e imaginário, imediato e prolongado, estimulante e deletério, defensável e contestável e assim por diante. A disposição de sediá-la implica constrangimentos, convencimentos, barganhas, pressões, interesses confessos e escusos, enfim, trata-se de algo que extrapola os pontos de vista maniqueístas. É fácil dizer: "Lula deveria ter dito não à Blatter, à Teixeira e tantos quantos tivessem insinuado em realizar a Copa no Brasil". Mas pensando nas possibilidades a partir de sua posição, a questão adquire outra conotação, pois a oportunidade era sedutora, e diria mesmo constrangedora, como seria a qualquer outro presidente naquelas circunstâncias. Então a questão, me parece, precisa ser pensada tendo em vista as circunstâncias - ou a conjuntura, o contexto, a configuração, seja lá qual o termo que se deseje utilizar. E o mesmo vale para os governadores dos 12 estados que serão sedes. Como os governos de Minas Gerais e da Bahia - um opositor e um aliado de Lula - poderiam deixar de candidatar seus estados para os jogos, mesmo sabendo que para tanto teriam de bancar a construção ou a reforma dos estádios? Não é que não poderiam. A questão é sobre o ônus, sobretudo político, afinal na ocasião da escolha as pesquisas indicam que a opinião pública era favorável ${ }^{8}$.

\footnotetext{
${ }^{8} \mathrm{O}$ ponto de vista da "opinião pública" aferido pelas agências de pesquisa de mercado não deve ser tomada como uma verdade, mas é verdade que ela orienta certas decisões políticas. Segundo a colunista do Painel, do Jornal Folha de São Paulo (23/12/2007), o próprio governo federal incluiu uma pergunta sobre a Copa no Brasil quando encomendou pesquisa para saber da avaliação de seus projetos sociais. A resposta foi que $82 \%$ aprovavam o Brasil como sede da Copa de 2014. No entanto, em pesquisa da agência Data Folha, realizada em $2010,57 \%$ dos brasileiros se disseram contra a utilização de recursos públicos em estádios (disponível em: http://datafolha.folha.uol.com.br/po/ver_po.php?session=1019, acesso em 12/5/2012).
} 
Se a Copa pode ser vista como um empreendimento comercial, para bem compreendê-la seria pertinente pensá-la no mesmo registro de outras grandes obras em curso no país e então se poderia avaliar melhor certas questões, como a relação entre o público e o privado, que está posta desde o dia em que se começou a veicular a possibilidade do Brasil ser sede. Trata-se, pois, de uma tarefa bem mais dispendiosa intelectualmente do que uma tomada de posição pró ou contra a realização do evento. Não podemos ter a pretensão de esgotar o assunto em duas dezenas de páginas e num momento em que as obras estão em andamento, mas nada justifica a paralisia intelectual. Sendo assim, proponho-me aqui uma interpretação sobre o fato, já consolidado, da escolha do Brasil como sede. O objetivo é desnaturalizar esta escolha mostrando que o Brasil não é sede apenas porque a FIFA tem um sistema de rodízio para contemplar diferentes continentes e países afiliados, nem porque houve um conchavo entre Blatter e Lula, ou entre eles e as empreiteiras. Destaco o protagonismo da FIFA nesse processo, o que não se configura como uma descoberta. A originalidade talvez esteja em tratá-la como uma agência privada, e isso implica em considerar legítimas as suas pretensões de lucrar com a copa. Desse ponto de vista é possível identificar algumas estratégias da FIFA que talvez sejam singulares quando comparadas ao mundo dos negócios, sendo a principal delas o comprometimento público, não raro pelo constrangimento, do Estado - através de seus representantes, obviamente - na consecução da parceria.

Além desse preâmbulo, o texto está articulado em outras duas partes. A que segue trata de mostrar que a copa é, entre outras coisas, uma mercadoria, mas não porque a FIFA a registrou como propriedade sua, antes porque ela é uma modalidade de bem simbólico largamente apreciado em escala planetária - e tendo isso claro a FIFA a patenteou. Para tanto apresento, rapidamente, os dois principais sistemas de disputas futebolísticas, o clubismo e o nacionalismo, com ênfase na dimensão simbólica que os orienta. A FIFA arbitra os dois sistemas, mas é notadamente sobre o segundo que ela exerce seu poder quase absoluto. $\mathrm{Na}$ última parte, busco reconstituir os principais momentos que levaram à definição do Brasil 
como sede da Copa, explicitando as estratégias das principais entidades envolvidas no processo: a CBF, a FIFA e a presidência da república. Dou ênfase à solenidade que definiu o Brasil como sede tratando-a como um rito de passagem no qual é explicitado, por parte da FIFA, promotora do cerimonial, que o Brasil é parceiro na realização da Copa e isso é uma responsabilidade que terá graves consequências para a imagem do país caso o evento não seja bemsucedido.

\section{A COPA COMO MERCADORIA E O LUGAR DA FIFA NESSE NEGÓCIO}

A FIFA detém os direitos comerciais da Copa e ela os comercializa com um amplo leque de multinacionais interessadas em veicular seus produtos à copa e na copa ${ }^{9}$. A Copa nos moldes como é exigida pela FIFA custa caro e ela própria provavelmente não teria como bancá-la sem parcerias. O fato de que os parceiros que mais investem - ou gastam? - sejam entes públicos, no caso Estados nacionais, não deveria passar desapercebido. Por que empresas privadas, incluindo-se clubes de futebol, não poderiam ser os parceiros preferenciais da FIFA? Uma das respostas possíveis é de que só os Estados nacionais podem, efetivamente, oferecer tudo o que a FIFA demanda, pois além de estádios atualizados em todos os quesitos, incluindo-se conforto, a FIFA também exige três outros itens que empresas privadas teriam dificuldade de oferecer: segurança às delegações, autoridades e turistas(torcedores); [b] meios de mobilidade - aéreo e terrestre, entre e dentro das cidades; [c] proteção legal aos seus parceiros e patrocinadores comerciais quem mais poderia impedir que durante a copa de 2014 se venda apenas cerveja da marca Budweiser nos estádios e no entorno deles?

\footnotetext{
${ }^{9}$ Segundo a própria FIFA, "A Copa do Mundo da FIFA África do Sul 2010 foi transmitida para todos os países e territórios do planeta, inclusive a Antártida e o Círculo Polar Ártico, produzindo recordes de audiência para várias emissoras ao redor do globo. A audiência domiciliar da competição alcançou mais de 3,2 bilhões de pessoas, compreendendo $46,4 \%$ da população mundial, considerando os telespectadores que acompanharam pelo menos um minuto de cobertura." Disponível em: http://pt.fifa.com/worldcup/archive/southafrica2010/organisation/ media/newsid=1473439/index.html. Acesso em 15/5/2012.
} 
Para entender um pouco melhor esse intrincado negócio é preciso tratar a própria copa como uma mercadoria e explicitar algumas de suas facetas ${ }^{10}$. Não se trata de imputar-lhe, por conta disso, uma conotação pejorativa. Num sentido amplo, mercadoria é todo o objeto, material ou simbólico, que é sujeito à transação num dado mercado. A copa, em suas partes ou na totalidade, responde plenamente a este conceito, sendo um "bem" - no sentido de mercadoria - comparável a outras modalidades de produções simbólicas como o são, por exemplo, um concerto musical, uma peça de teatro, um filme e assim por diante ${ }^{11}$. A noção de "bem simbólico" pode ser aplicada a quaisquer eventos esportivos, mesmo os que não são comercializados, mas é em relação àqueles cuja realização é hoje dirigida ao e pelo mercado que ela se presta efetivamente. Cada modalidade esportiva ou cada evento em particular, possui características que lhe são próprias e, portanto, uma forma de produção e consumo igualmente distintos. O que permite colocar as olimpíadas - que reúnem uma multiplicidade de esportes, mas não todos aqueles passíveis de comercialização - e as copas de futebol em paralelo é o viés nacionalista que ambos os eventos mobilizam. O papel das agências esportivas - no caso a FIFA e o COI - é decisivo na orquestração de uma dada ordem, indispensável à viabilização do esporte no mercado de bens simbólicos.

Está fora de discussão o fato de que um jogo de copa do mundo possa ser tratado como uma mercadoria, afinal é um espetáculo e,

\footnotetext{
${ }^{10}$ Para uma discussão mais detalhada a respeito, conferir Damo (2011).

11"Bem simbólico" é um conceito de uso corrente na obra de Pierre Bourdieu, tendo sido forjado a partir de seus estudos sobre o campo artístico, notadamente a literatura e as artes plásticas (1999 e 2007). O conceito gerou controvérsias, pois a noção de "bem" foi empregada como sinônimo de mercadoria, desagradando boa parte dos produtores artísticos que tendiam a se perceberam como criadores de algo que, supostamente, seria a antítese do mercado, do valor econômico e de toda a sorte de coisas mundanas. Em que pese possa ter havido alguns exageros e maus entendidos, dois aspectos pretendidos pela análise bourdiana são pertinentes para compreender também o universo esportivo. Um deles é a convicção de que numa sociedade na qual o mercado é uma instituição tão desenvolvida quanto a nossa, quase todas as atividades são permeadas por ele - o que inclui a religião, o sexo, a política e, porque não, as artes, os esportes e assim por diante. Um segundo aspecto importante tem a ver com a própria definição de mercado atribuída por Bourdieu (2003), como o local de encontro entre uma oferta e uma demanda, o que permite um uso ostensivo desse conceito, parcialmente descolado do espaço das transações propriamente financeiras e, sobretudo, de certos modelos de mercados capitalistas.
} 
como o próprio termo sugere, sua razão de existir tem a ver com o fato de vir a ser apreciado por um público que paga, direta ou indiretamente, para tanto. Há muitas formas de consumir um jogo, e elas dependem de como o sujeito é envolvido neste universo. Raros são os torcedores que vão ao estádio para admirar a performance corporal dos jogadores. Vai-se para torcer por uma das partes envolvidas na disputa e esta adesão é, via de regra, anterior à frequentação aos estádios. A força com que um sujeito é atraído para a audiência dos jogos e um amplo leque de noticiário que lhe diz respeito, é uma força de natureza simbólica, mais sedutora do que coercitiva.

Como escreveu Bromberger (1995, 1998), o interesse pelo jogo passa pelo engajamento e isto pressupõe a constituição de uma sensibilidade, que é ao mesmo tempo estética, sentimental e política. A economia das emoções esportivas - ou mesmo futebolísticas ainda carece de entendimento mais aprofundado, mas está claro que, para realizá-la, é imprescindível que se proceda a uma análise do emaranhado simbólico que dá sentido para os fatos propriamente esportivos - um lance, uma vitória, um gol, etc. Sem este suporte significativo não há como compreender a especificidade das emoções que se produzem neste meio.

Isso se torna mais claro se considerarmos que no universo do futebol de espetáculo os jogos não existem isoladamente, como mercadorias avulsas. Essa modalidade de enfrentamento, denominada de "amistoso", é cada vez mais rara. Não são apenas as regras do jogo que garantem a sobrevivência do futebol, são também esses arranjos a que se denominam copas ou campeonatos, cujo objetivo é agregar valor que de outro modo os jogos não teriam - deve se pensar aqui na diferença entre dois jogos entre os mesmos adversários, um deles amistoso e outro valendo por uma competição. O que fazem as competições como a copa do mundo é conectar os jogos, atribuindo-lhes um sentido de totalidade, invariavelmente através da hierarquização, ao mesmo tempo em que oferece um sentido mais amplo para as disputa. Um campeonato é via de regra um evento cíclico e repetitivo - como as copas, realizadas de quatro 
em quatro anos -, ao longo do qual é constituída uma espécie de narrativa, como os capítulos de um romance ou de uma novela. Sem se estender a este respeito, é importante fixar a idéia de que os jogos não possuem valor isolado. À diferença do que supõem alguns analistas, o espaço do futebol de espetáculo é relativamente bem organizado, do contrário não seria visado pela indústria do entretenimento. Ou por outra, é o próprio mercado quem contribui para promover a ordem que lhe interessa: orquestrando os circuitos de disputas, estabelecendo conexões entre eles, arranjando e promovendo os jogos, definindo os horários e assim por diante ${ }^{12}$. A própria Copa é, na verdade, a fase final de uma competição planetária, na qual se enfrentam aproximadamente duas centenas de selecionados nacionais, subdivididas de acordo com um critério geopolítico, organizadas pelas 6 confederações - entrepostos da FIFA.

No amplo espectro do mundo do futebol existem dois sistemas de disputas capazes de produzir esta misteriosa absorção de público em larga escala: o clubismo e o nacionalismo. Em todos os jogos que observamos, há duas equipes se enfrentando, mas elas representam, salvo exceções, um clube ou uma nação ${ }^{13}$. Do ponto de vista do modus operandi do sistema simbólico que dá suporte a um e a outro circuito, não há diferença expressiva. A diferença é antes de conteúdo. O que move o clubismo são as rivalidades entre clubes: rivalidades atávicas, como aquelas, que sustentam os derbies locais, regionais ou nacionais, ou circunstanciais, como aquelas decorrentes das disputas ao longo de um campeonato.

\footnotetext{
${ }^{12} U m$ dos exemplos mais evidentes dessa interferência pode ser ilustrado pela pressão da Rede Globo na formatação do campeonato brasileiro por pontos corridos, a partir de 2003. A grande vantagem da televisão quando se adota esta modalidade de disputa é a definição do calendário dos jogos, do início ao fim do certame, o que acarreta não apenas facilidade no planejamento da programação mas também a venda de pacotes aos torcedores.

${ }^{13}$ Isso não se observa nos jogos improvisados, chamados no Brasil de peladas, que se caracterizam pela bricolagem das regras, dos equipamentos, do tempo e do espaço. Nesses casos simplesmente não há uma comunidade de pertencimento a qual as equipes correspondem e, portanto, também não há publico. Existem ainda outras modalidades de disputas que fogem ao clubismo e ao internacionalismo - torneios entre funcionários de empresa, entre turmas escolares ou mesmo entre escolas -, mas nenhuma dessas variantes é profissionalizada.
} 
O circuito clubista é, de fato, um amplo e heterodoxo conjunto de competições envolvendo times que representam agremiações normalmente chamadas de clubes, grêmios ou associações - Athletic Club de Bilbao, Grêmio Foot-Ball Porto Alegrense, Associazione Sportiva Roma, etc. Se pensado em diacronia, o circuito clubístico tem uma origem local, ainda que em muitos locais diferentes, compreendendo, quase sempre, as fronteiras de uma dada cidade ou área metropolitana. Esses circuitos se expandiram de forma gradativa, em função de variáveis para além do espectro esportivo densidade populacional, facilidade de transporte, segmentação de territórios, etc. Em certos países, como o Brasil, as subdivisões regionais serviram como um entreposto até o estabelecimento do certame nacional, circunscrito pelas fronteiras do Estado-nação ${ }^{14}$. Na Europa e na América do Sul, as competições continentais possuem forte tradição, sendo disputadas há várias décadas. A partir de 2000 foi criado pela FIFA um torneio anual reunindo os clubes vencedores das competições continentais, mas desde a década de 1960 se realizava, por iniciativa dos próprios clubes e de agentes não ligados diretamente à FIFA, um jogo entre o campeão sul-americano e europeu, cujo vencedor designava-se o título de "campeão do mundo".

$\mathrm{O}$ circuito nacionalista (em que pese o nome não seja o mais adequado) é aquele no qual competem as equipes cujos atletas são recrutados de acordo com critérios de identificação auferidos pelos Estados nacionais. Ao contrário do clubismo, em que há intensa circulação de jogadores, inclusive para além das fronteiras nacionais, no espectro das seleções nacionais as regras são bastante rígidas, não havendo propriamente o intercâmbio, apenas a naturalização de alguns atletas, algo com o que a FIFA está preocupada e deseja

\footnotetext{
${ }^{14} \mathrm{Na}$ maioria dos países nos quais o futebol é um esporte popular, há competições nacionais. Naqueles em que prevalecem os critérios propriamente futebolísticos, a tendência é de se reproduzir a concentração de renda e, portanto, a concentração de clubes das regiões mais abastadas. No caso do Brasil, que serve como ilustração, cujo Estado é composto por 26 unidades federativas, e o campeonato "brasileiro" é disputado por 20 clubes na primeira divisão, nota-se que 15 deles são sediados em 4 estados e mais da metade em apenas 4 cidades. Tal concentração faz com que nada menos do que 20 unidades federativas não possuam representação, e ainda assim o certamente é chamado de nacional ou brasileiro. Esta, no entanto, não é uma peculiaridade do Brasil, pois na Argentina e na Inglaterra, por exemplo, a concentração é ainda maior. Não é o caso da França, no entanto, cujas ligas profissionais só admitem um clube por cidade, dispersando as representações.
} 
restringir (DAMO, 2006). Este é o circuito em relação ao qual a FIFA detém maior controle, embora não seja completo. As competições continentais de seleções, por exemplo, são geridas pelas respectivas confederações e o caso da Copa da União Européias das Federações de Futebol (UEFA), que reúne as seleções européias, está entre os eventos mais importantes do calendário futebolístico internacional e, como tal, é altamente rentável.

O circuito clubístico, à exceção da Copa do Mundo de Clubes, não é do domínio comercial da FIFA, embora as regras ali seguidas, tanto do jogo quanto nas negociações envolvendo os clubes, sejam chanceladas por ela. O clubismo se fragmenta segundo o domínio das confederações continentais - que organizam um campeonato de clubes, tal é o caso da Libertadores da América, organizado pela Confederación Sudamaricana de Futbol (CONMEBOL) -, nacionais - a CBF, por exemplo, organiza o campeonato brasileiro, atualmente com quatro subdivisões (série A, B, C e D) - e, quando é o caso, de certames regionais - no Brasil as 27 afiliadas da $\mathrm{CBF}$ organizam os chamados campeonatos estaduais e outras competições do gênero. As confederações e federações podem, inclusive, delegar a organização desses circuitos clubísticos a entidades especializadas, contratadas ou mesmo forjadas pelos clubes. As ligas nacionais européias e mesmo a Champions League - integrada pelos campeões nacionais europeus - são eventos cuja ingerência da FIFA é consideravelmente menor quando comparada ao que se passa na América do Sul, por exemplo, onde a CONMEBOL organiza a Libertadores da América - o equivalente da Champions League. Esses arranjos diferenciados são produtos de disputas, a principal delas entre dirigentes de clubes e de federações, razão pela qual o conjunto é bastante heterodoxo do ponto de vista organizacional e dinâmico do ponto de vista político e econômico.

Nos últimos anos, a FIFA tem ampliado seu domínio para além do chamado football association, tendo-se tornado responsável pela organização de outras competições, tais como as copas do mundo de Futsal e de Beach Soccer. A entidade também passou a organizar 
a Copa do Mundo de Futebol Feminino, incluindo-se as versões para mulheres com idade abaixo de 20 e de $17 \operatorname{anos}^{15}$. A cereja do bolo, não é difícil imaginar, é chamada simplesmente de Copa do Mundo - para sermos precisos deveríamos dizer Copa do Mundo de Futebol Masculino ou, seguindo Blatter, Copa do Mundo de Futebol da FIFA, pois de fato ela detém os direitos comerciais sobre a competição. A razão é um tanto óbvia: além de ser o evento campeão de audiência é, provavelmente, aquele que consegue amealhar maior retorno em termos de patrocínio e comercialização - antes mesmo da bola rolar, a FIFA havia arrecado algo em torno de R \$ 5,6 bilhões em 2010, sendo que todas as previsões são de aumento de receitas para $2014^{16}$.

Em se tratando de eventos esportivos, a tradição é um elemento importante, e a Copas possui este atributo, pois aquela a ser realizada em 2014 será a 19ª edição. Pode-se até não apreciar o futebol, mas a Copa implica o confronto de equipes que vestem as cores nacionais. Como as equipes formadas por atletas recrutadas entre os cidadãos natos (ou naturalizados), uma importante condição de verossimilhança com a guerra é cumprida, razão pela qual as seleções suscitam o mesmo referencial simbólico - o que equivale, em certos casos, a séculos de tradições. Certas seleções, como é frequente em relação à que representa o Brasil, tendem a suscitar adesões para além das fronteiras nacionais, mas é entre elas que se espera um investimento afetivo maior. $\mathrm{O}$ mais importante de ser notado no caso do circuito nacionalista é que a base simbólica das disputas excede, consideravelmente, o espectro futebolístico. Tanto é verdade que as copas do mundo - ou outras competições nas quais a seleção nacional está envolvida - tendem a suscitar o interesse de um público mais amplo daquele habitualmente interessado em jogos de futebol.

\footnotetext{
${ }^{15}$ Este é o conjunto das competições sobre as quais a FIFA dispõe dos direitos econômicos: Copa do Mundo de Futebol, Copa do Mundo Feminina, Copa do Mundo de Futsal; Copa do Mundo de Beach Soccer; Copa do Mundo Sub-20, Copa do Mundo Sub-17, Copa do Mundo de Futebol Feminino Sub-20 e Sub-17, Torneio Olímpico de Futebol (realizado durante as Olimpíadas), Copa das Confederações (realizada a um ano da Copa do Mundo, no país sede) e a Copa do Mundo de Clubes (atualmente realizada em Abuh Dabhi, nos Emirados Árabes).

${ }^{16 "}$ "Com a venda das cotas de patrocínio da Copa de 2010, a FIFA embolsou 2,6 bilhões, segundo o secretário-geral da FIFA, Jérôme Valcke. O valor é $30 \%$ superior ao da Copa da Alemanha, em 2006. Para o Brasil, a FIFA estima que o montante chegue a 2,9 bilhões." (Valor Econômico, 3/5/2010).
} 
A Copa emergiu como um corolário de seu tempo, o período entre as duas grandes guerras de origem européia, sob o pretexto de fazer a guerra por outras vias, uma vez que os esportes modernos estão impregnados pelos valores disseminados pelo processo de civilização (ELIAS; DUNNING, 1992). A Copa se associou ao nacionalismo convencional e atualiza a nação enquanto categoria política e sentimental - mais esta do que aquela. Até a metade do século XX, pelo menos, as Copas - e mesmo as olimpíadas - estavam impregnadas pelos valores nacionalistas, e de algum modo ainda estão. Mas é fato que os esportes adquiriam, progressivamente, um estatuto ético e estético autônomo. O que a FIFA fez, ao perceber que as copas haviam sido impregnadas pelo nacionalismo, foi convencer o mercado que isso poderia ser explorado comercialmente. Poucos empreendimentos, no presente, são tão exitosos em extrair dividendos econômicos do substrato simbólico que dá sentido à nação enquanto uma categoria de pertencimento. Pela facilidade de ser explorado, este simbolismo faz da Copa uma espécie de petróleo de superfície. Quem detém os royalties é a FIFA, embora ela não os tenha adquirido ou herdado, apenas se apropriado. Ela detém a patente tecnológica e prospecta globalmente. Mas precisa de um lugar para realizar o evento e parece ser bastante persuasiva, pois até o presente não tem faltado interessados.

Não se pode dizer que a FIFA não tenha sido uma agência pretensiosa desde sua fundação, mas a hegemonia do futebol que detém no presente não provém da origem. Quando foi criada, em 1904, a FIFA parecia ser uma dissidência da International Football Association Board (IFAB), agência controlada pelos britânicos desde sua fundação, em 1882, e auto-incumbida de salvaguardar as regras do football association ${ }^{17}$. Todavia, a relutância dos britânicos em se integrarem às competições internacionais - eles disputariam uma Copa do Mundo pela primeira vez em 1950 - fez com que a IFAB

\footnotetext{
${ }^{17} \mathrm{Em} 1913$ a FIFA foi reconhecida pela IBFA e em 1958 as entidades entraram em acordo, constituindo uma parceria. Com o desenvolvimento do futebol como espetáculo, a gestão dos negócios se tornaram mais importantes do que a das regras, atribuição da IBFA, e esta passou a existir à sombra da FIFA. Os dirigentes britânicos jamais assimilaram esta mudança no equilíbrio de forças e ainda lembram com certa nostalgia da gestão de Sir Stanley Rous, o último sportman a dirigir a FIFA (JENNINGS, 2011, p.19-28).
} 
perdesse espaço para a FIFA, embora as descrições acerca da organização das primeiras copas revela que a FIFA desempenhou, a este respeito, um papel bem menos centralizador do que no presente $^{18}$. De outro lado, predominavam as competições locais e regionais, de modo que eram as agências que atuavam nesses domínios quem exerciam o efetivo controle sobre as competições. Além disso, havia um número expressivo de jogos amistosos, incluindo-se excursões - um mercado que floresceu no pós-guerra , que eram agenciadas de forma segmentada, por agentes que atuavam à maneira dos empresários circenses. Ainda em 1950, ocasião em que o Brasil organizou a Copa, as referências à FIFA são bem menos constantes do que no presente. Houve, efetivamente, uma espécie de disputa pela sede, mas a FIFA não vendeu o que quer que seja e nem fez exigências estapafúrdias em relação aos estádios. O único estádio novo construído para a Copa foi o Maracanã, menos por exigência da FIFA e mais pelo desejo de exibição internacional dos brasileiros, uma campanha orquestrada na mídia do Rio de Janeiro e movida a controvérsias, mas que resultaria na edificação do maior estádio do mundo (MOURA, 1998).

É com a chegada de João Havelange à presidência, em 1974, que a FIFA adquire, gradativamente, os contornos atuais ${ }^{19}$. Por um lado, Havelange investiu na ampliação do número de afiliados, incorporando, basicamente, nações de pequeno porte e pouco expressivas futebolisticamente, fora do continente europeu. A estratégia, notadamente eleitoreira, em que pese fosse alardeada como cosmopolita e inclusiva, garantiria Havelange no poder por longos 25 anos, e Blatter por outros 14, por enquanto. Também serviria para dar sustentação ao argumento de que a FIFA é uma instituição que se ocupa das coisas do futebol em escala planetária, conferindo tratamento igualitário a todas as nações. Havelange e Blatter (que foi seu secretário e sucessor) trataram de aproximar a

\footnotetext{
${ }^{18} \mathrm{Na}$ primeira Copa, realizada no Uruguai, participaram 13 seleções. Apenas quatro delegações européias estiveram presentes -sete eram sul-americanas e duas norte-americanas. Em 1934, na Itália, fez muita propaganda, sob o auspício de Mussolini, mas a competição orquestrada para a Itália vencer contou com a participação de 16 seleções, 12 delas européias, mais Brasil, Argentina, EUA e Egito.

${ }^{19}$ Sobre a gestão de Havelange à frente da FIFA conferir Favero (2010).
} 
FIFA de empresas multinacionais, inicialmente do ramo esportivo e depois de qualquer uma que dispusesse de muito dinheiro para gastar em publicidade. A comercialização dos direitos de transmissão dos jogos sofisticou-se a tal ponto que a FIFA vende às empresas, na atualidade, até o direito delas se anunciarem como parceiras da instituição - assim sendo, os contratos são de exclusividade por ramo de atividade: uma empresa de material esportivo, de telefonia, de refrigerante e assim por diante ${ }^{20}$.

$\mathrm{Na}$ medida em que flerta tanto com o mundo dos negócios como com o mundo da política - dentro e fora do espaço do futebol de espetáculo - a FIFA é uma agência que desafia as definições convencionais. Em antropologia, costuma-se não confrontar as autorepresentações, sejam elas de indivíduos ou instituições. No caso da FIFA, levar tal postulado ao pé da letra, tratando-a como uma agência de promoção do futebol e da integração entre os povos - "For the Game. For the Word", é o slogan oficial - seria no mínimo risível, pois ela atua em diversas frentes e manipula politicamente sua identidade conforme as circunstâncias. Pela volúpia com que vem atuando no mercado de "bens simbólicos", tendo valorizado exponencialmente seus produtos, seria apropriado pensá-la como gestora de uma joint venture - ou conglomerado, se preferirem especializada na produção de eventos futebolísticos. Além de controlar as regras do football association, a partir da incorporação da IFAB, a FIFA também dita normas que dizem respeito aos procedimentos que devem ser seguidos por suas afiliadas, às quais os clubes são geralmente vinculados. Tal governo é garantido, fundamentalmente, pela imposição de uma justiça própria - dita

\footnotetext{
${ }^{20} \mathrm{~A}$ mesma estratégia é seguida pela $\mathrm{CBF}$, que exibe, na atualidade, nada menos do que 10 marcas de patrocinadores. Como a FIFA impede que elas sejam usadas nos uniformes de jogos, as marcas aparecem nos uniformes de treinamento, em painéis nos estádios, nos fundos das entrevistas coletivas, etc. O que atrai muitas marcas, no entanto, não é este tipo de exposição, mas a possibilidade de usar as insígnias da seleção em seus produtos, com frases do tipo: "patrocinador oficial da seleção". Com a realização da Copa no Brasil a cotação da CBF aumentou já aumentou $256,5 \%$, se comparados os valores amealhados em $2010 \mathrm{com}$ aqueles de quatro anos antes. Só em patrocínio a CBF arrecadou 214 milhões em 2010. Dados publicados pela revista Isto É, Especial Copa 2014, p. 24-9.
} 
desportiva - que impede os clubes de recorrem à justiça comum, aquela atinente ao Estado ${ }^{21}$.

De um ponto de vista político, a FIFA opera em dupla perspectiva. Por um lado, ela exerce seu poder internamente, tendo ingerência sobre todas as matérias relevantes que digam respeito ao futebol profissional. Ela delega poderes, obviamente, às confederações - que são entidades de abrangência continental-, às federações - de amplitude nacional - e, se as federações nacionais estiverem de acordo, como no caso do Brasil, a entidades regionais. Todavia, as hierarquias são bem claras e a FIFA situa-se no topo. Isso não implica ausência de conflitos e ameaças ao monopólio, mas é fato que seus dirigentes tem tido habilidade em lidar com tais situações. As ameaças vêm do circuito clubista, em especial do mais poderoso deles, o europeu, cujos clubes ameaçam, entre outras coisas, exigir das seleções nacionais uma compensação por ceder seus jogadores. Eles também reivindicam o pagamento de seguro, para o caso de lesões, e outras exigências que poderiam onerar o caixa das federações e todas as competições envolvendo seleções ${ }^{22}$.

Noutra perspectiva, a FIFA atua externamente, representando os interesses do futebol profissional como um todo. Neste caso ela se apresenta como uma agência supranacional e seguidamente compara-se às agências supranacionais, como a ONU. Diferente desta, no entanto, a FIFA reveste-se de uma finalidade laica, cuja missão seria a difusão do futebol e do fair-play ${ }^{23}$. Atenta ao papel que desempenha, e aos dividendos que tal condição lhe propicia, a

\footnotetext{
${ }^{21}$ Esta justiça aplica-se às transgressões às regras do jogo, o que é essencial para impedir a violência, e também as transações envolvendo a compra e venda de jogadores, o que é fundamental para organizar este mercado.

${ }^{22}$ Recentemente o Bayer de Munique ameaçou recorrer à justiça comum contra a seleção holandesa caso esta não negociasse uma reparação pelo fato dos jogadores Van Bommel e Robben terem retornado da Copa 2010 com lesões graves, que os mantiveram por quase uma temporada afastados dos gramados. Segundo um dirigente do Bayer, se não houvesse acerto o contencioso poderia se transformar num novo caso Bosman, dadas as repercussões no futebol profissional. (Valor Econômico, 11/11/2010)

${ }^{23} \mathrm{Como}$ afirma Jérôme Champagne, ex-diplomata francês e ex-diretor de assuntos internacionais da FIFA, " [...]le président Blatter est reçu partout comme un chef d'État lorsqu'il rend visite à une fédération nationale. S'il n'est pas appelé auprès du chef de l'État, il voit le chef du gouvernement ou au moins le ministre des Affaires étrangères" (Walh, 2004, p. 23).
} 
FIFA tem o cuidado estratégico de se manter ao mesmo tempo próxima e distante das tensões diplomáticas. Ela proíbe, por exemplo, a filiação de mais de uma entidade representativa por nação. Além de precaver-se em relação às dissidências e, por extensão, dos conflitos no interior do próprio domínio, a FIFA evita que o futebol por ela controlado sirva de pretexto para alavancar reivindicações separatistas - o caso das restrições às federações regionais espanholas é emblemático a este respeito. A FIFA não se opõe a certos rituais, como aquele que teve lugar na Copa de 1998, por ocasião do confronto entre Irã e EUA. Os jogadores iranianos entregaram flores aos seus adversários antes do enfrentamento entre as seleções e o mundo esportivo registrou o gesto como um espetáculo extraordinário, de como o futebol pudesse promover a paz e reconciliar os povos, mas é forçoso ter de dizer que isso permaneceu no plano da imaginação, pois no espectro das atribuladas relações políticas e comerciais entre os dois países a atitude significou um zero absoluto. Para evitar atribulações a FIFA interditou a veiculação de mensagens políticas por parte dos atletas e, pouco antes da Copa da África do Sul, proibiu manifestações de ordem religiosa ${ }^{24}$.

Para maximizar a rentabilidade de seus eventos a FIFA não restringe suas parcerias às agências que já fazem parte da joint venture que ela lidera - no caso a $\mathrm{CBF}$, as federações estaduais e os clubes. Tampouco se satisfaz em comercializar as imagens e a publicidade de tais eventos com multinacionais às quais se refere como parceiras. A FIFA busca, e mais uma vez parece estar sendo muito bem sucedida, parcerias com os Estados-nações. Sob o pretexto de que a copa projeta o país internacionalmente, atraindo turistas e investidores, barganha compromissos que vão desde a isenção de impostos, passando por segurança, infra-estrutura - em transporte de pessoas e de informações - e, sobretudo, disponibilização de estádios compatíveis com padrões que ela idealiza. Seu modus operandi em relação às Copas, de capitalizar os ganhos e dividir as

\footnotetext{
${ }^{24}$ Atribui-se o desencadeamento de tal iniciativa ao fato dos jogadores brasileiros terem exagerado na exibição de mensagens cristãs durante a comemoração da Copa das Confederações, em 2009. Seria temerária aos negócios planetários da FIFA a associação de sua marca a uma matriz religiosa específica, seja ela qual for.
} 
despesas, é um contrasenso à lógica do mercado, mas isso não tem sido um problema à FIFA pois ele sempre encontra parceiros. A escolha do Brasil como a sede da vez pode ajudar a compreender como essa magia se processa.

\section{Dos BASTIDORES AO RTO DE INSTITUIÇÃO}

Auto-proclamada a "ONU do futebol", a FIFAusa a itinerância das copas para tornar verossímil este slogan, repetido nas mais diversas modalidades de publicações, incluindo-se as acadêmicas. $\mathrm{O}$ fato da FIFA ser exitosa em se fazer passar por uma entidade não comercial é, na verdade, a alma do seu negócio, pelo menos quando se trata de barganhar verbas governamentais ou de impor sua própria justiça a todos quantos integram o universo do futebol de espetáculo. Enfim, para não macular o slogan, a Copa de 2014 caberia à COMMEBOL, e deveria ser realizada por uma de suas 10 afiliadas. Seria uma oportunidade que não aparecia desde a Copa de 1978, realizada pela junta militar argentina, e poderia demorar para se reapresentar.

Ricardo Teixeira, então presidente da CBF, candidatou o Brasil. As especulações jornalísticas dão conta de que esta seria uma estratégia urdida por Teixeira visando a sucessão de Blatter, projetada para depois de 2014. Desde que o Brasil realizasse um bom evento, Teixeira se tornaria o sucessor óbvio de Blatter, que fora secretário de João Havelange, ex-sogro de Teixeira ${ }^{25}$. Mas se ele não candidatasse o Brasil, provavelmente passaria à história como um néscio que desperdiçou a oportunidade de ouro. Teixeira pode ficar marcado com outros rótulos, mas jamais com sendo indiferente aos negócios. Por iniciativa ou constrangimento ele levou até a COMMEBOL a postulação do Brasil.

\footnotetext{
${ }^{25} \mathrm{O}$ jornalista Juca Kfouri, desafeto de Teixeira de longa data, chegou a especular que este estava interessado em suceder Blatter já em 2007, e a Copa no Brasil poderia ter sido o produto de um acordo. Esse tipo de especulação, que é próprio do mundo da política, faz parte do cotidiano do futebol. Qualquer que seja a trama, pode-se afirmar que os caminhos que levaram o Brasil a ser sede são bem mais complexos e dependem da urdidura institucional, e não apenas de vontades pessoais - conquanto estas não sejam desprezíveis.
} 
Barganhar o apoio da COMMEBOL era de longe a tarefa mais fácil. Difícil mesmo era convencer a opinião pública brasileira de que a CBF teria competência para conduzir a organização do megaevento, que o próprio Teixeira seria capaz de portar-se de forma transparente e, sobretudo, de que ao fim e ao cabo, a conta não recairia nos cofres públicos. Havia muitos nós a serem desatados, o principal, talvez, sendo a própria reputação de Teixeira, que em 2003 estava no purgatório, mas pouco antes estivera no inferno.

Durante os anos de 2000 e 2001, Teixeira foi alvo de uma Comissão Parlamentar de Inquérito (CPI), que realizou uma devassa nas contas da CBF e de seu presidente. A CPI foi batizada informalmente de "CPI da Nike", pois uma das justificativas de origem era investigar a suposta intromissão da Nike, patrocinadora oficial da seleção, na gestão da CBF. A celeuma se arrastava desde o final da Copa de 1998, quando o Brasil foi goleado pela França por 3 a 0 , na ocasião em que Ronaldo Nazário, à época no auge da carreira, tivera uma crise convulsiva na concentração, poucas horas antes do início do jogo. Em que pese o inusitado, Ronaldo foi escalado, mas sua performance ficou aquém do usual. Uma das lendas a respeito conta que Ronaldo havia entrado em campo sem as mínimas condições atléticas, por pressão da multinacional que, além do contrato com a $\mathrm{CBF}$, tinha exclusividade para explorar a imagem do jogador e, por conta disso, o queria em campo na final ${ }^{26}$.

A CPI não produziu só fatos hilários. A persistência de seu proponente e presidente, Aldo Rebelo, então deputado pelo PCdoB de São Paulo, impôs vários revezes à "bancada da bola", um grupo de deputados dos mais variados partidos, vinculados direta ou indiretamente a clubes e federações. $\mathrm{Na}$ época a própria $\mathrm{CBF}$ mantinha uma "embaixada" em Brasília; uma mansão alugada para fazer agrado a políticos de todas as ideologias. A "embaixada" foi mobilizada e a "bancada da bola" fez o impossível para obstruir os trabalhos da CPI. Com parcimônia, Aldo Rebelo e Silvio Torres -

\footnotetext{
${ }^{26}$ Como é de rotina nas CPIs, nesta também teve lugar para o prosaico, e Ronaldo não apenas foi convocado a depor senão que teve de explicar a um deputado por que o Brasil perdeu por 3 a 0. Diante da pergunta insólita o craque deu uma resposta de letra, literalmente: "foi porque a França fez três gols e nós não fizemos nenhum, excelência!".
} 
deputado pelo PSDB de São Paulo e relator da CPI - articularam um grupo de parlamentares ligados a partidos de esquerda e assim conseguiram algumas vitórias frente ao lobby orquestrado pela CBF. Ricardo Teixeira foi interrogado pela CPI e se enrolou. A contabilidade da CBF foi questionada, pois apesar do aumento exponencial das receitas a entidade se mantinha deficitária. O relatório final escancarava problemas gravíssimos na gestão do futebol profissional, incluindo o desdém da entidade com relação à exploração de menores em centros de formação, o trânsito fácil de agentes de jogadores especializados em falsificar documentos, a falta de transparência na gestão financeira da CBF e sérios indícios de desvio de recursos, com o favorecimento do próprio Ricardo Teixeira. A "bancada da bola" fez o impossível para impedir que este relatório fosse votado e sugeriu outro, que não comprometesse a CBF. Pressentindo a derrota, Aldo Rebelo decretou o fim da CPI sem a apresentação de qualquer relatório, mas entregou o que havia produzido para diversas entidades públicas para que fossem aprofundadas as investigações. Não se tem notícia de nenhum movimento nesse sentido, mas o relatório virou livro - "CBF-Nike (REBELO; TORRES, 2001) - e teve ampla divulgação midiática.

Bancar a candidatura de um país à sede de copa do mundo demanda credenciais que Teixeira não poderia exibir àquela altura e, diga-se de passagem, não se tem notícia de que tenha movido uma palha para mudar o que quer que seja depois da exposição da CPI. Teixeira e a CBF podem não ter mudado, mas o cenário mudou. A má reputação dos dirigentes do futebol brasileiro é tamanha que Teixeira seria apenas mais um entre eles. Sua estratégia foi a mesma de outros políticos em situação de risco: tratar de manter o mandato - o que para Teixeira não seria problema, pois mantinha o apoio da maioria das federações estaduais - e esperar as más notícias se dissiparem. A péssima campanha da seleção brasileira nas eliminatórias para a Copa de 2002, tornavam Teixeira um alvo fácil e rotineiro, mas quando a situação tornou-se preocupante, ele contratou o técnico Luis Felipe Scolari, de reputação inquestionável e excelentes performances à frente de Grêmio (1993-1996) e Palmeiras (1997-2000). Felipão poderia não ser o nome ao gosto de 
parte da crônica esportiva, notadamente do Rio de Janeiro, que o viam como adepto de um estilo de jogo que seria a antítese do futebolarte, mas sua reputação de ser hostil à intromissão de dirigentes nos assuntos de campo e vestiário conferiram à escolha de Teixeira rara credibilidade. A seleção se classificou na terceira colocação com 30 pontos, o mesmo número do Paraguai, à léguas da Argentina, que chegou a 43 e foi a primeira colocada. Como já havia ocorrido em outras ocasiões, o time chegou àquela Copa desacreditado, mas fez uma campanha irretocável e trouxe o título ${ }^{27}$.

Sem dúvidas, o pentacampeonato deu novo fôlego à Teixeira, de movimentação discreta durante toda a competição. Já na seqüência daquele ano Teixeira deu passos importantes para implementar o Campeonato Brasileiro por pontos corridos, com turno e returno, uma demanda de quase duas décadas da elite clubística nacional e da grande mídia especializada. A principal emissora de televisão nacional, a Rede Globo, investiu pesado no novo formato de disputa, inaugurando a venda de jogos aos assinantes - o chamado pay per view. Ao impedir que os clubes rediscutissem a fórmula da competição de um ano a outro, como sempre faziam quando havia necessidade de acomodar o interesse de um dos grandes - em casos de rebaixamento, sobretudo - Teixeira dava a impressão de estar moralizando o futebol. Poupado pela Rede Globo, que agora era parceira da CBF, Teixeira recobrou o ânimo e ainda em 2003 candidatou o Brasil junto à CONMEBOL, conquanto esta só viesse a discutir a sério a candidatura sulamericana para a Copa de 2014 três anos depois ${ }^{28}$.

Em 2002 Luis Ignácio Lula da Silva venceu as eleições presidenciais, e o Brasil passou a ter no seu comando um presidente apaixonado por futebol, como jamais visto na sua história desse país.

\footnotetext{
${ }^{27}$ Por inconveniência ou zelo à imagem do grupo e da CBF, nessa ocasião não houve contrabando quando do retorno da delegação brasileira, diferentemente do que se passou em 1994, quando atletas e dirigentes tentaram entrar no Brasil, retornando dos EUA, sem declarar as aquisições ao fisco. O episódio ficou conhecido como o "voo da muamba".

${ }^{28}$ Argentina e a Colômbia, cujas postulações não pareceriam minimamente viáveis, jamais se apresentaram como verdadeiras concorrentes. A Colômbia se reapresentou já no final dos prazos, mas sem quaisquer credenciais acabou sumariamente descartada por Blatter.
} 
Quando o presidente Lula sugeriu que se fizesse um jogo festivo contra a seleção do Haiti, para consolidar e publicizar a missão de paz chefiada pelo Brasil naquele país, em 2004, Ricardo Teixeira não perdeu a oportunidade. Ao invés de recrutar uma equipe de suplentes, mais do que suficiente para golear a frágil equipe haitiana, Teixeira mandou o técnico convocar os titulares, entre os quais incluíam-se Ronaldinho Gaúcho e Ronaldo Nazário - o primeiro seria eleito o melhor jogador da FIFA naquele mesmo ano e o segundo, que já havia sido escolhido em três edições, havia sido o grande nome da conquista brasileira de dois anos antes. Os haitianos, que adoram a seleção brasileira, não cabiam em si quando os Ronaldos e sua trupe desembarcaram em Porto Príncipe em agosto de 2004. Os jogadores foram saudados como pop stars, da chegada à partida. Desfilaram em tanques sob o delírio da população nas ruas e golearam a seleção local por 6 a 0 , um placar elástico para um evento denominado como "jogo da paz". Em todo o caso, a guerra era civil, e não entre brasileiros e haitianos.

Do ponto de vista futebolístico o jogo não possuiu sequer o status de um treinamento para a seleção brasileira, mas pelo viés diplomático foi um gol de placa. O governo brasileiro aproveitou a ocasião para exibir-se como líder de uma missão de paz da ONU, pouco importa se era no combalido Haiti. Já o presidente da CBF foi bem sucedido na aproximação com o presidente Lula. $\mathrm{O}$ fato de o Brasil ter se tornado, três anos mais tarde, sede da Copa, não é culpa do Haiti, é claro, e nem se explica apenas pela aproximação entre Teixeira e Lula. Todavia, esta aproximação foi essencial, pois sem trânsito no governo a CBF não teria qualquer possibilidade de levar adiante a postulação encaminhada à CONMEBOL. A FIFA, como se sabe, não quer saber de desavenças com governos, do mais democrático ao despótico, do transparente ao corrupto. Tanto é verdade que Teixeira e o Comitê Local da Copa, que ele havia criado e presidia com a finalidade de gerenciar o evento de 2014, foram às favas quando o trânsito do agora ex-presidente da $\mathrm{CBF}$ tornou-se inviável em Brasília, mais ou menos depois que a presidente Dilma assumiu o poder, em 2010. 
A escolha do país sede da Copa não é algo que a FIFA realize numa disputa de cara ou coroa. Embora a instituição tenha passado por várias crises de credibilidade nos últimos anos, como tem sido amplamente noticiado, e de seu estatuto ser ambivalente, é inegável seu sucesso na realização das últimas copas. Isso mostra que a instituição acumulou um savoir faire nesse domínio. A FIFA possui uma equipe de profissionais de diversas especialidades, liderada, nos últimos anos, por Jérôme Walke. Engana-se, no entanto, quem imagina ser a expertise da FIFA circunscrita à produção do caderno de encargos - que explicita, nos detalhes, como deve ser a infra estrutura para a copa, em especial os estádios - ou à supervisão das obras . Além da venda dos direitos de imagem, a FIFA tem parcerias comerciais com multinacionais que, sabidamente, não estão no negócio por fair-play. A FIFA tem os direitos legais sobre a Copa do Mundo de futebol - tanto é que ela anuncia o evento como sendo a "Copa do Mundo de Futebol da FIFA" - e isto vale uma fortuna, mas valeria bem menos, talvez nada, se ela tivesse que bancar os custos para a realização desse megaevento.

Compreendendo a Copa como um evento comercial, a FIFA trata o país-sede como parceiro, procurando convencê-lo das vantagens de sediar o evento e, sobretudo, precavendo-se, de todas as formas possíveis, de que sua parte no negócio seja lucrativa. $\mathrm{O}$ sucesso do empreendimento, a FIFA sabe muito bem, depende da performance do seu principal parceiro de realização - o que não implica dizer que seja um parceiro dos lucros, evidentemente. AFIFA seduz o país-sede alardeando que "a copa é uma oportunidade" algo vago, portanto - que cabe ao país aproveitar. O que lhe importa, sobremaneira, é que o país-sede ofereça as condições para a realização do evento, e isso implica no dispêndio de recursos públicos. $\mathrm{Na}$ verdade, ao invés de dizer que a FIFA escolhe o país-sede, seria mais condizente afirmar que ela compromete um governo e, segura disso, anuncia o país ao qual aquele governo corresponde como o local da Copa. 
O que faz o COI não difere substantivamente, pois também ele exige um comprometimento concertado dos governos - cidade, estado e federação. Mas no caso do COI existe um protocolo orientando o processo de escolha, o que inclui duas rodadas eliminatórias, a primeira delas decidida por um comitê restrito, a segunda pelo voto de aproximadamente uma centena de membros do COI. Acusações de venda de voto têm sido freqüentes e em certos casos bem fundamentadas, pois o próprio COI se encarregou de expurgar alguns de seus membros. Também é notório o trabalho de bastidores realizado pelas candidaturas, como ocorreu no caso da escolha do Rio de Janeiro, cujo lobby brasileiro envolveu um repertório amplo de iniciativas e de instituições, indo do Ministério das Relações Exteriores, que recomendou aos embaixadores a inclusão dos membros do COI em suas recepções, ao escritor Paulo Coelho, que no dia da votação final distribuiu exemplares de seus livros às esposas dos membros do COI presentes em um almoço especial em Copenhague (DAMO; OLIVEN, 2012).

Todavia, a decisão do COI é tomada por um colegiado, enquanto a da FIFAé feita por um comitê influenciado de perto pela presidência da FIFA. A concorrência para a realização das olimpíadas é maior, não apenas porque são cidades ao invés de países, mas também porque o COI não apresenta restrições a priori (como no caso da FIFA, que ao definir previamente um continente acaba circunscrevendo, sobremaneira, o leque de possibilidades). Enfim, há mais publicidade, incluindo-se uma sessão de apresentação das candidaturas aberta aos concorrentes. O próprio sistema de votação, que vai excluindo as cidades concorrentes, oferece senão a certeza ao menos a ilusão de que os membros do COI estão agindo por convicção. Não é que a dimensão política esteja ausente, mas o processo todo se assemelha muito a uma decisão parlamentar, familiar às democracias modernas. Não diria que a escolha das cidades sedes pelo COI seja um exemplo de accontability, mas o processo é bem mais transparente do que aquele empreendido pela FIFA. 
A aproximação de Teixeira com Lula por ocasião do amistoso no Haiti foi um marco importante para destravar as negociações da CBF com a presidência da República, e a eficácia simbólica daquele evento fez crer que o Brasil, como nação, poderia tirar proveito da popularidade do time da CBF. Todavia, foi a conversa reservada de Blatter com o presidente Lula, em 28 de setembro de 2006, na semana anterior ao primeiro turno da eleição presidencial, da qual Lula esperava sair reeleito, que selou a parceria. Para Lula, aquela conversa não poderia ter sido agendada em melhor hora, pois ela praticamente confirmava o Brasil como sede da Copa de 2014, algo noticiado havia pelo menos seis meses, depois de declarações do presidente Blatter. À saída do encontro eles poderiam ter pousado para as fotos e pronunciado abertamente que a Copa de 2014 seria no Brasil. Mas isso não aconteceu, pois o anúncio acabou ofuscado por um episódio de campanha, de ampla repercussão na imprensa nacional, desfavorável à candidatura de Lula - o chamado "episódio dos aloprados".

Quem saiu vitorioso daquele encontro foi Blatter, pois mesmo que Lula não fosse reeleito, seria improvável que um outro governo tivesse interesse e envergadura política para declinar do compromisso assumido por Lula. Até se poderia culpabilizá-lo por bancar as exigências da FIFA, mas recuar seria improvável. Que a FIFA não tinha outras alternativas àquela altura é um fato, embora ela jamais admitirá isso. Comenta-se que a Inglaterra poderia constituir um plano B ou mesmo o Canadá. No primeiro caso, isso implicaria, no mínimo, na ruptura da tradição de realizar o mundial em continentes diferentes, no segundo seria levar a copa para um país que não tem tradição em copas e tão pouco tem o futebol como um esporte nacional. Não é que Blatter se importasse tanto com isso, mas precisava de um argumento consistente para declinar da candidatura brasileira. E talvez a FIFA quisesse, de fato, realizar a copa no Brasil, afinal o país tem ao menos duas credenciais indiscutíveis: é um país futebolístico e possui a reputação de ser belo, festivo e acolhedor no espectro internacional. 
O que Blatter necessitava, e com urgência, era de um compromisso do governo brasileiro. Diferentemente de Ricardo Teixeira, que anunciava a Copa de 2014 como aquela que entraria para a história por ser bancada com recursos privados ${ }^{29}$, Blatter jamais se mostrou afeito a bravatas. Como disse à saída do encontro com Lula, em 2006, um ano antes do anúncio oficial: "necessitamos de garantias governamentais para a organização de um evento tão importante" 30 . Foi assim que a FIFA procedeu em relação à África do Sul e até com a Alemanha - embora neste caso a barganha tenha sido menor - por que seria diferente com o Brasil? De parte do governo federal, não se falou em momento algum na construção de estádios, mas em criar linhas de crédito, e viabilizar as obras de infra-estrutura para receber os torcedores estrangeiros e garantir a geração de imagens. Os gastos com essas obras poderiam ser facilmente justificados como investimentos, e de fato estão sendo, de modo que a copa por vezes parece ser uma fábrica ou uma usina, quando é um catalizador, se tanto. Ninguém levou muito à sério o caderno de encargos, de tal maneira que as exigências que lá estavam só se mostraram incômodas quando a FIFA tratou de efetivá-las, mas isso só ocorreu muito tempo depois do anúncio oficial do Brasil como sede da Copa.

A solenidade que ocorreu em Zurique, em 30 de outubro de 2007, encaixa-se perfeitamente no conceito de "rito de instituição". Num sentido mais amplo, trata-se de um rito de passagem cuja finalidade é promover a separação de algo ou de alguém de uma classe a outra - de solteiro à casado, de pagão à batizado, de estudante à profissional e assim por diante. Num sentido mais preciso, conforme a contribuição de Bourdieu (2008, p. 101), "[...] o ato [rito] de instituição é um ato de comunicação de uma espécie particular: ele notifica a alguém sua identidade, quer no sentido de que ele a exprime e a impõe perante todos [...], quer notificando-lhe assim com autoridade o que esse alguém é e o que deve ser". Os ritos são o que

\footnotetext{
${ }^{29}$ Sobre o tema, conferir, entre outras, as reportagens "Copa-14 já apela a verba pública" (Folha de São Paulo, 5/8/2009) e "2014: e agora?", publicada pela Revista Isto É - Dinheiro (9/7/2010). Esta última está disponível em: http:/www.istoedinheiro.com.br/noticias/27949_2014+E+AGORA. ${ }^{30}$ Folha de São Paulo, 29/09/2006.
} 
são pela crença partilhada, por aqueles que dele participam, de que a encenação, incluindo-se o que é dito, tem um poder diferenciado, quase mágico, de fazer valer cada gesto e cada palavra.

Em certo sentido, o "brasil" é um nome, uma entidade abstrata, um Estado-nação imaginado, para seguir os termos de Anderson (1989). Não tem, pois, agência própria; é uma coisa, literalmente. Como existe uma comunidade de sentimento que se reconhece por este nome, então ele se torna Brasil. A comunidade em questão delega a um de seus membros o poder de representá-la, e então o Brasil pode ir a Zurique e vir a ser consagrado sede de uma copa. Quem tem o poder de consagração é o presidente da FIFA, pois a Copa lhe pertence. Trata-se de uma propriedade sui generis, pois é algo que não existe a não ser de quatro em quatro anos. A Copa é uma montagem global, sem um vínculo e muito menos uma identificação geográfica precisa. $\mathrm{Na}$ verdade, ela adquire esta identificação quando se realiza de fato, e assim passa para a história como a Copa deste ou daquele país.

Como era sabido de antemão que o Brasil seria o país escolhido pela FIFA, não houve um clima de expectativa tal qual o que seria observado dois anos depois, por ocasião da escolha do Rio de Janeiro como sede da Olimpíada 2016. Nem por isso as autoridades brasileiras deixaram de viajar à Zurique para acompanhar a solenidade. A delegação incluía dirigentes de futebol, ex-jogadores como Dunga (que na ocasião também era técnico da seleção) e Romário, mais de uma dezena de governadores, o então presidente Lula e seu Ministro dos Esportes, Orlando Silva, e até o escritor Paulo Coelho. Os grandes jornais impressos deram destaque de capa ao evento e diversas emissoras de televisão abriram espaço na programação ordinária para transmitir o cerimonial em tempo real, mas não havia multidão aguardando o anúncio, nem houve sobressaltos com a decisão. De qualquer forma, o ritual instituiria o Brasil pela segunda vez na história como o país-sede do principal evento esportivo planetário, e isso foi tratado como um motivo de júbilo nacional. 
No momento mais aguardado do cerimonial, aquele no qual o chefe autorizado profere as palavras derradeiras - autorizo, batizo, declaro e assim por diante -, Joseph Blatter tomou a palavra e depois de um breve preâmbulo, exaltando o Brasil pela sua contribuição ao futebol, abriu um envelope que the fora entregue lacrado, algo absolutamente teatral aquela altura, e pronunciou de dedo em riste: "O Comitê executivo da FIFA decidiu dar a responsabilidade, não só o direito, mas a responsabilidade de organizar a copa mundial da FIFA de futebol 2014 ao país - e depois de breve suspense, retirando a papeleta do envelope -: Brasil ${ }^{31}$. A platéia aplaudiu, mas não houve comemoração; nada que pudesse ser comparado ao estardalhaço, regado a lágrimas, promovido pela delegação brasileira quando do anúncio do Rio de Janeiro como sede olímpica.

Consumava-se, de qualquer sorte, a consagração, muito embora as palavras proferidas por Blatter viessem carregadas. Seguindo as pegadas do filósofo austríaco John Austin (1990), cujo livro How to do things with words ${ }^{32}$, tornou-se um clássico nas ciências sociais, convém prestar a devida atenção ao que foi dito por Blatter e, sobretudo, ao fato de que ao dizer o que disse estava tornando pública não apenas uma expectativa da FIFA, mas um compromisso forjado nos bastidores. À diferença do que repercutiram os locutores brasileiros que transmitiam a cerimônia, dando conta de que o Brasil acabara de se "tornar sede" da Copa de 2014, o presidente da FIFA disse, claramente, algo um tanto diverso, a começar pelo fato de que "a FIFA decidiu"; que decidiu "dar a responsabilidade"; e insistiu que não era "só o direito, mas a responsabilidade"; e frisou, claramente, que não se tratava de sediar, apenas, mas de "organizar" a "copa mundial da FIFA" - note-se, no detalhe, que a copa é "da FIFA". O fato de ter dito isso com o indicador em riste, apontado na direção da platéia, onde estava o presidente Lula, dispensa comentários.

\footnotetext{
${ }^{31}$ Disponível em http://www.youtube.com/watch?v=IFxgh1vOv4E.

${ }^{32}$ Como fazer coisas com palavras seria a tradução literal, mas na edição brasileira de 1990 o título foi traduzido para "Quando dizer é fazer" (AUSTIN, 1990). Em todo o caso, para o argumento deste texto, não faz diferença.
} 
Tais gestos e palavras não foram gratuitos. O que se fez foi reforçar, de forma teatralizada, visando com isso imprimir mais vigor ao conteúdo da fala, o fato de que o governo brasileiro havia empenhado algo muito valioso nos bastidores dos encontros precedentes. A FIFA punha a Copa na negociação, mas exigia a devida contrapartida. No seu pronunciamento após o anúncio, Lula parecia desconfortável, tendo feito uma brincadeira sem graça com Romário, que junto com Dunga e Ricardo Teixeira haviam se deslocado da platéia até a frente do palco do cerimonial. As primeiras palavras do presidente foram de agradecimento, mas logo em seguida ele deu a entender que havia entendido o recado de Blatter. Disse que se tratava de uma ocasião de muita alegria e de festa, mas também de responsabilidade. "Quero tranqüilizar os dirigentes da FIFA", prosseguiu Lula, destacando que a responsabilidade não era apenas sua, mas também dos governadores presentes e do presidente da CBF. "No fundo, no fundo, estamos assumindo uma responsabilidade enquanto nação, enquanto Estado brasileiro, para provar ao mundo que temos uma economia crescente e estável, com uma estabilidade [política] conquistada. Somos um país com muitos problemas, mas somos um país de homens determinados a resolvermos estes problemas"33. De fato, as autoridades brasileiras saíram de Zurique com uma pesada responsabilidade: ou a Copa de 2014 será um sucesso ou o Brasil será culpabilizado.

A FIFA não tem autoridade para impor a quem quer que seja a responsabilidade de organizar suas competições. Ou, dizendo o mesmo de outra maneira, foi o Brasil que pleiteou a Copa de 2014. Para ser preciso, o mais correto seria dizer que determinados dirigentes - de futebol e de outros ramos de atividade - pleitearam tal incumbência convencendo-nos que ela valeria à pena. Agora é toda a nação que se percebe comprometida em realizar a tarefa que Blatter designou, sob o risco, nada desprezível, de um vexame internacional. De um ponto de vista estritamente prático, isso não acarretaria maiores consequências a quem quer que seja, exceto

${ }^{33}$ Disponível em http://www.youtube.com/watch?v=oHDpugDHF7M\&feature=relmfu. Acesso em 10/4/2012. 
alguns poucos implicados diretamente com o evento. Mas seria comprometedor para um país que tem pretensões de ocupar um lugar importante no cenário político e econômico internacional.

Muitos nomes que protagonizaram a candidatura do Brasil já não constam nas fotografias dos eventos oficiais de preparação para a Copa. Lula encerrou seu mandato em alta, batendo recorde de aprovação popular e elegendo como sucessora Dilma Roussef, uma ex-guerrilheira que jamais havia disputado uma única eleição. Seu sucesso, não passou, segundo os comentaristas da hora, pela Copa ou pelas Olimpíadas, embora ele tenha atuado decisivamente no concurso de ambas. Dilma também caiu nas graças da opinião pública, surpreendendo os prognósticos mais otimistas. Uma das marcas de seu primeiro ano de governo foi a demissão de vários ministros envolvidos com denúncias de corrupção. Orlando Silva, dos Esportes, foi um deles. Em seu lugar entrou Aldo Rebelo, e não foi apenas para manter o PCdoB à testa do Ministério mais importante para a Copa e as Olimpíadas. Foi um sinal de que o trânsito de Ricardo Teixeira pelo Planalto estava obstruído, definitivamente. Novamente bombardeado por denúncias de corrupção, dentro e fora do Brasil, Teixeira desta vez fraquejou. Ele e seu Comitê Local da Copa foram atropelados por Blatter e Vacke, seu escudeiro. Outros nomes poderão mudar até 2014, mas a parceria entre a FIFA e o Estado brasileiro tudo indica que resistirá, em que pese alguns atritos.

\section{Considerações finaIS}

Não há um único texto tratando dos megaeventos que não se reporte à extensão e à diversidade dos mesmos, razão que os tornam fascinantes ao amplo espectro das ciências sociais (GOING, 2012). Todavia, os megaeventos cobram seu preço a quem procura abordálos. A dificuldade de produzir uma síntese consistente é seguidamente referida, conquanto não cessem as tentativas, mais ou menos bem sucedidas, de efetivá-las. O que fazemos, em geral, é recortar certos elementos - como o econômico, o político, o jurídico, o cultural e assim indefinidamente - de acordo com as respectivas especialidades. De fato, não há muitas alternativas a não ser perspectivar os 
megaeventos: um olhar a partir de $\mathrm{x}$, uma análise do aspecto $\mathrm{y}$, uma abordagem sob o ângulo da teoria $\mathrm{z}$ e assim por diante.

De um antropólogo seria de se esperar que falasse sobre a dimensão cultural da Copa e das Olimpíadas. Que escrevesse sobre o modo como o futebol dramatiza a sociedade brasileira e como isso haverá de ser potencializado com a realização da Copa em nosso próprio domínio. Algo sobre identidade nacional não poderia deixar de ser referido, obviamente. Há, no entanto, dois bons motivos pelos quais evitei uma abordagem dessa natureza, embora fosse impossível ignorar completamente tais questões. Um desses motivos tem a ver com o fato de que muito já se escreveu sobre isso, inclusive no Brasil. Faz trinta anos que DaMatta organizou a publicação de "Universo do Futebol", um espécie de paradigma sobre o tema no espectro das ciências sociais brasileiras - e mesmo em outras áreas ${ }^{34}$. As gerações subseqüentes, favorecidas pelo ambiente menos hostil às investigações, avançaram em múltiplas direções e, sem contradizer o primado de que o futebol dramatiza certos dilemas nacionais, lançaram-se em outras direções e referenciais bibliográficos. Visto pela perspectiva dessa produção, o texto de DaMatta revela-se uma interpretação cativante, mas frágil e insustentável em muitos aspectos, dado que ele propôs uma exegese totalizante ${ }^{35}$. Escrito como contraponto à visão hegemônica de então no âmbito das ciências sociais, segundo a qual o futebol seria um tema frívolo e irrelevante, pois estava associado a tudo o que havia de mais alienante, o texto apresenta argumentos que, vistos de um ponto de vista descolado do contexto, poderiam ser tomados como apologéticos. Talvez seja por conta disso que muitos dos seus argumentos continuam sendo referidos com freqüência para justificar

\footnotetext{
${ }^{34}$ O primeiro capítulo da coletânea, "Esporte na Sociedade: Um Ensaio Sobre o futebol Brasileiro", é de autoria do próprio DaMatta e nele o autor procura mostrar que o futebol é um fato social e cultural digno de ser investigado pelas ciências sociais por veicular diversas tensões que estão presentes no espetro mais amplo da sociedade brasileira - a tensão entre destino e biografia, sorte e competência, respeito às regras e desejo de grupos corporativos, etc.

${ }^{35}$ DaMatta afirma ser o futebol democrático, por permitir a quem quer que seja a experiência do êxito e do fracasso. Isso faz sentido quando se pensa a partir do ponto de vista do público, engajado na torcida por times que representam clubes ou nações, mas nada informa sobre a dinâmica política das instituições que disputam o controle desse esporte, a começar pelas regras do jogo, que são exclusividade da FIFA.
} 
a realização de investigações, como se o mérito dependesse do objeto. Esta etapa de produção, de viés ensaísta, foi em boa medida superada, mesmo porque não resta dúvidas de que a seleção brasileira é um símbolo laico da nação, mas não se pode passar a vida repetindo isso.

Um segundo motivo para transpor os clichês habituais do dueto cultura e identidade nacional tem a ver com as tensões teóricas em torno desses conceitos no espectro da antropologia. Nas últimas décadas, ambos os conceitos foram apropriados - ou reapropriados - em diferentes instâncias, para muito além das fronteiras da antropologia. Do marketing à pedagogia, de militantes pelos direitos sexuais a índios e camponeses, cultura e identidade adquiriram usos tão heterogêneos que perderam, em parte, a capacidade explicativa. No presente, a antropologia interessa-se, sobretudo, pelos usos políticos e até econômicos desses termos, evitando entrar na disputa por eles, como ocorre quando se reivindica a autoridade conceitual. Não há dúvidas em relação ao poder que tem a copa e as olimpíadas de mobilizar os sentimentos nacionais, e não há qualquer contestação quanto ao fato de que, sendo esses eventos realizados no Brasil, tal poder se multiplica. Afinal, não seremos avaliados apenas pela performance futebolística dos atletas, mas também pelo desempenho de arquitetos, engenheiros, operários, controladores de vôo, taxistas, governantes, agências de fiscalização e assim por diante.

Quando se trata de megaeventos, pensa-se, em geral, muito mais na extensão do que na duração. Pensando na relação entre o Brasil e a Copa de 2014 a partir da duração, tentei me fixar na escolha do país como sede e nos agentes e agências envolvidos. Pelo impacto de megaeventos como a copa e as olimpíadas possuem, a escolha do país ou cidade sede tem destacada importância. Conquanto a organização desses eventos seja uma rotina para o COI e para a FIFA, não o é para os países e cidades sedes, uma vez que a repetição, algo raro, é bastante espaçada. Daí porque o processo de escolha é tão importante, como a licitação de uma grande obra o é no âmbito do Estado ou a fusão de grandes empresas no campo dos negócios privados. Há interesses econômicos em jogo? Sem dúvida. E há mobilização política, envolvendo governos, instituições 
esportivas e mesmo empresas de outras especialidades construtoras, mídias, etc? Claro que há, não seria de se esperar o inverso. As decisões são tomadas nos bastidores? Óbvio, pois é assim que se fazem negócios de vulto. Então o povo é ludibriado? Não, em hipótese alguma. Basta ler os comentários em blogs ou prestar atenção nas conversas cotidianas para se ver que tudo isso é discutido, tensionado e criticado, embora efetivamente, pelo menos até o presente, tenhamos poucos movimentos organizados tentando fazer um contraponto consistente.

Procurei encaminhar a discussão de forma não reducionista, evitando tomar partido de alguns debates em curso, notadamente sobre a pertinência do governo empenhar recursos públicos. Isso daria uma discussão a parte, pois a questão é mais complexa do que se supõe, mas eu penso que conseguiria desenvolver um bom argumento mostrando que os investimentos nos estádios são excessivos, para dizer o mínimo. Como isso está dito em muitos outros lugares, evitei a repetição. Mas faço um adendo importante a esta discussão: o fato das clivagens regionais não terem sido devidamente problematizadas. A disputa entre os estados, que já é rotina quando se trata de seduzir grandes empreendimentos às custas de desoneração fiscal, repetiu-se no caso da concorrência para receber os jogos da Copa. Seria um bom tema para ser abordado em profundidade ${ }^{36}$.

Em todo o caso, o uso de recursos públicos em grande monta e, sobretudo, em algo que não é tido como de primeira necessidade, será sempre objeto de tensão. Digo tensão, e não reprovação. $\mathrm{O}$ potlatch é um dos cerimoniais mais instigantes já registrados e discutidos pela antropologia. O termo é proveniente da língua chinnok e pode ser traduzido como dom ${ }^{37}$. Praticado por diversos grupos nativos da região noroeste da América do Norte, o potlatch teve seu

\footnotetext{
${ }^{36} \mathrm{O}$ fato de morar em Porto Alegre me coloca numa situação incômoda - embora não seja nascido aqui e tão pouco afinado com o gauchismo. Pois aqui se reforma um estádio e se constrói outro (que sequer será palco dos jogos da Copa), não sem a generosidade estatal, mas com o suporte principal da iniciativa privada. Se é possível aqui, por que não em outros estados/cidades?

${ }^{37}$ Para uma descrição detalhada do potlatch, tanto dos fatos sociais quanto da repercussão no âmbito da antropologia, conferir Schulte-Tenckhoff, 1986.
} 
auge provável no período que antecedeu à chegada dos colonizadores, em meados do século XIX, e consistia em festividades nas quais os chefes locais ofertavam hospitalidade e presentes a outros chefes, não raro a tribos inteiras. $O$ potlatch realizava-se nos meses de outono e inverno, pois nesta época do ano a população se sedentarizava, acentuando, sobremaneira, a vida social e o consumo das provisões amealhadas pela caça e pesca praticadas durante os meses de primavera e verão. As celebrações importantes - batizados, casamentos, etc - ocorriam durante este período e se caracterizavam pelos gastos em profusão, o que implicava a liquidação de quase toda a riqueza acumulada. Realizar o potlatch não era apenas uma obrigação para um chefe local, mas uma ocasião na qual teria a oportunidade, face a outros chefes, de mostrar o quão próspero era seu grupo. Quanto mais abundante houvesse sido a provisão, mais suntuoso o dispêndio, mas não era incomum que, capturados pela competição, alguns chefes fossem levados a gastar além do limite das suas possibilidades e, por extensão, do grupo - o que poderia tornar penosa a própria sobrevivência. Antes mesmo dos antropólogos terem descoberto o potlatch, os missionários já haviam imposto restrições morais e os colonizadores sanções legais. Mesmo que essa fosse uma região de fartura, soava irracional aos olhos dos europeus, que um chefe se desse o direito de gastar ritualmente o trabalho de seu povo, e o que é pior, com a anuência deste.

Para um país como o Brasil, sediar a Copa e as Olimpíadas em tão curto espaço de tempo soa um tanto extravagante. Parece irracional que uma nação com sérios entraves nas áreas da saúde, moradia, educação, segurança e tantas outras, subtraia delas um centavo que seja para empenhá-lo na preparação de um megaevento esportivo, quanto mais em dois. Se consideramos os valores econômicos amealhados pela FIFA e pelo COI com a comercialização desses eventos, chega a ser escorchante repassar os custos da organização dos megaeventos aos cidadãos brasileiros, como ocorreu com os sul-africanos. No entanto, são tão poucas as vozes que manifestam contrariedade que seria o caso de nos perguntarmos se não estamos todos mistificados pela mídia, pelo marketing esportivo, pela propaganda dos governos e, sabe-se lá, por quais outras forças 
misteriosas. Mas se deixássemos essas hipóteses em suspense e, no lugar delas, forjássemos outras, inspiradas no potlatch, quiçá não poderíamos lançar alguma luz sobre todo esse mistério? Afinal, num e noutro caso, os chefes estão dispondo da riqueza de seu povo para bancar de um ritual extravagante, que veicula sentimentos de orgulho e poder, um espetáculo de pura exuberância e luxúria, e talvez por isso tolerado e mesmo incentivado. 
The desire, the right and the duty - The plot that brought the World Cup to Brazil

Abstract: This paper aims to discuss the main events, as well as the role of agents and institutions that have made Brazil the 2014 World Cup host country. The objective is to denaturalize this choice by showing that the country is not based merely because FIFA has a rotation system, or because there was a conspiracy between Lula and Blatter. I highlight the role of FIFA in the process, treating it as a private agency, which involves consider legitimate its pretension to profit from the World Cup. I try to show how the Brazilian government was being seduced by sports officials and the public to endorse the candidacy, paying for it a contested high economic value, also taking risks to have its status scratched in case of the World Cup is not a success.

Keywords: World Cup. Events. Soccer. Brasil. Anthropology.

El deseo, el derecho y el deber - La trama que llevó la Copa al Brasil.

Resumen: Este trabajo tiene como objetivo discutir los principales eventos, así como el papel de los agentes y de las instituiciones, que han hecho del Brasil el país anfitrión del Mundial de 2014. El objetivo es desvirtuar esta elección mostrando que el país no se ha establecido como sede simplemente porque la Federación Internacional de Fútbol Asociado (FIFA) tiene un sistema de rotación, o porque hubo una conspiración entre Blatter y Lula. Destaco el papel de la FIFA en ese proceso, tratándola como una agencia privada, lo que implica considerar sus demandas legítimas para beneficiarse con la Copa. Trato de mostrar como el gobierno brasileño fue seducido por las autoridades deportivas y por la opinión pública para respaldar la candidatura, pagando por ella un valor económico muy alto y contestado, además de arriesgarse de salir con su status malo por no ser la Copa un éxito.

Palabras-clave: Copa del mundo. Eventos. Fútbol. Brasil. Antropología. 


\section{REFERÊNCIAS}

ANDERSON, Benedict. Nação e consciência nacional. São Paulo: Ática, 1989.

ANDREFF, Wladimir. Économie internationale du sport. Grenoble: PUG, 2010.

AUSTIN, John. Quando dizer é fazer: palavras e ação. Porto Alegre:Artes Médicas, 1990.

BOURDIEU, Pierre. A economia das trocas lingüísticas. São Paulo: EDUSP, 2008.

BOURDIEU, Pierre. A Distinção. Crítica Social do Julgamento. São Paulo:Edusp/ Porto Alegre: Zouk, 2007.

BOURDIEU, Pierre La fabrique de l'habitus économique. Actes de la Recherche, n. 150, p. 79-90, 2003.

BOURDIEU, Pierre. O mercado de bens simbólicos. In:

A Economia das

Trocas Simbólicas. 5. ed. São Paulo: Perspectiva, 1999.

BROMBERGER, Christian. Passions pour 'la bagatelle la plus importante du monde': le football. In: (org.) Passions ordinaires: football, jardinage, généalogie, concours de dicté.... Paris: Hachette Littératures, 1998. p. 271-308.

BROMBERGER, Christian. Le match de football: ethnologie d'une passion partisane à Marseille, Naples et Turim. Paris: Éditions de la Maison des sciences de l'home, 1995.

DA MATTA, Roberto. Universo do Futebol: Esporte e Sociedade Brasileira. Rio de Janeiro, Pinakotheke, 1982.

DAMO, Arlei. Produção e consumo de megaeventos esportivos - apontamentos em perspectiva antropológica. Revista Comunicação, Mídia e Consumo, São Paulo, v. 8, p. 67-92, 2011.

DAMO, Arlei e OLIVEN, Ruben. "La "gran ocasión". Brasil como sede de la Copa del Mondo de la FIFA de 2014 y de los Juegos Olímpicos de 2016". In: GOING, Ramón Llopis (ed.). Megaeventos Deportivos: perspectivas científicas y estudios de caso. Barcelona:Editora UOC, 2012. p. 227-245.

ELIAS, Norbert e DUNNING, Eric. A busca da Excitação. Lisboa, Difel, 1992.

FAVERO, Paulo Miranda. Os donos do campo e os donos da bola: alguns aspectos da globalização do futebol. Dissertação (Mestrado em Geografia). São Paulo: USP, 2010.

FRAGA, Gerson. A "derrota do Jeca" na imprensa brasileira: nacionalismo, civilização e futebol na copa do mundo de 1950. Tese de Doutorado. Programa de Pós-graduação em História. Porto Alegre: UFRGS, 2009. 
FREITAS Jr, Miguel Arcanjo de. No meio do caminho: tensões presentes nas representações sobre futebol e o ideal de modernidade brasileira na década de 1950. Tese de Doutorado. Programa de Pós-graduação em História. Curitiba: UFPR, 2009.

GAFFNEY, Christopher. Mega-events and socio-spatial dynamics in Rio de Janeiro, 1919-2016. Journal of Latin American Geography, Austin/Texas, v. 9,n.1,p. 7-29, 2010.

GOING, Ramón Llopis. Una Introducción el studio de los megaeventos deportivos desde las ciencias socials. In: Megaeventos Deportivos: perspectivas científicas y estudios de caso. Barcelona:Editora UOC, 2012. p. 11-22.

JENNINGS, Andrew . Jogo Sujo: o mundo secreto da FIFA. São Paulo: Panda Books, 2011.

MATHESON, Victor A. Efectos de los principales megaeventos deportivos em las economias locales, regionales y nacionales. In: GOING, Ramón Llopis (ed.). Megaeventos Deportivos: perspectivas científicas y estudios de caso. Barcelona:Editora UOC, 2012. p. 53-74.

MOURA, Gisella. O Rio corre para o Maracanã. Rio de Janeiro: Fundação Getúlio Vargas, 1998.

REBELO, Aldo; TORRES, Silvio. CBF-NIKE. São Paulo:Casa Amarela, 2001.

ROLNIK, Raquel. Megaeventos e violações de direitos humanos no Rio de Janeiro: Dossiê do comitê popular da Copa e Olimpíadas do Rio de Janeiro, 2011. Disponível em: http://comitepopulario.files.wordpress.com/2012/04/dossic3aamegaeventos-e-violac3a7c3b5es-dos-direitos-humanos-no-rio-de-janeiro.pdf. Acesso em: Acesso em: 5 maio 2012.

SCHULTE-TENCKHOFF, Isabelle. Potlatch: conquête et invention. Lausanne: Editions d'en bas, 1986.

WAHL, Alfred.Entretien avec Jérôme Champagne. Outre-Terre, Montpellier, n. 8, p. 21-25, 2004.

ZELIZER, Viviana. A negociação da intimidade. Vozes: Petrópolis, 2011.

Artigo convidado com revisão

Endereço para correspondência:

Rua Felipe Camarão 175/403

Bom Fim - Porto Alegre/RS

90035-141

ovimento, Porto Alegre, v. 18, n. 02, p. 41-81, abr/jun de 2012. 
